\title{
A REVIEW ON STATUS OF PRODU $\neg$ CTION OF LARGE CARDAMOM IN NEPAL AND ITS MARKETING IN NATIONAL AND GLOBAL SCENARIO
}

\author{
${ }^{* 1}$ Abishkar Khatiwada, ${ }^{1}$ Aadesh Subedi, ${ }^{1}$ Rashmi Dangol \\ ${ }^{1}$ B.Sc.Ag, Agriculture and Forestry University, Chitwan, Nepal \\ Email: 1abishkarkhatiwada11@gmail.com, aadeshsubedi2@gmail.com dangolrashmi012@gmail.com \\ Contact: ${ }^{1+977-9865029794,+977-9865121356,+977-9860640256}$
}

\section{Doi : 10.2478/mjhr-2019-0004}

\section{ABSTRACT}

The study mainly focuses on the status of production and marketing of large cardamom in Nepal and also compares these dimensions in the context of different countries. For the study mainly secondary data were collected from research articles, reports, publications and news articles. Large cardamom is the third most expensive crop and one of the major cash crops of Nepal. Nepal is the largest producer of large cardamom in the world followed by India and Bhutan. Taplejung, Sankhuwasabha, Panchthar and Illam are the four major districts that contribute more than $80 \%$ of the national production. Cardamom produced in Nepal is graded according to tail cutting after drying and packed in jute bag or plastic to export it to foreign countries. Nepal exports almost 90 percentage of its total cardamom production to India. In the global scenario, Guatemala is the largest exporter of cardamom (small and large combined) followed by India, Nepal, Singapore and Indonesia respectievly. It was found that the production of cardamom is declining in Nepal due to price fluctuation and viral diseases such as Chirkey, Furkey. Problem such as absence of unique HS code for large cardamom and 'duplicate large cardamom' are also seen in the market.

KEYWORDS: Chirkey, Furkey, HS code, tail cutting

\section{INTRODUCTION}

\subsection{BACKGROUND}

Large cardamom (Amomum subulatum Roxb.) or 'Alainchi' in nepali, known as 'queen of spices', also called 'grain of paradise', is a perennial herbaceous spice crop belonging to the family of Zingiberaceae. Large cardamom is the third most expensive spice in the world after saffron and vanilla. It is a shade loving plant and thrives well in a moist soil, which is maintained by water diverted from seasonal springs on the upper slopes [1]. The plant has several tillers consisting of pseudostems with leaves on the upper part and the inflorescence (spike) appears on the rhizome from the point where the pseudostem shoots [2]. The dried fruits of large cardamom is a high-value, low-volume spice crop widely used in foods, beverages, perfumes, and medicines [3]. It is featured heavily in curries, pickles and spice blends such as garam masala in South Asian countries, and is also consumed in gahwa, which is a popular cardamom coffee drink in Middle East [4]. It is used as species in ayurvedic medicine as it contains 2-3\% essential oils and other important compounds [5].

Large cardamom was introduced into Ilam (Nepal) in 1865 AD, by Nepalese laborers although, commercial cultivation started much later in $1953 \mathrm{AD}$ and further development of this crop began after the establishment of Cardamom Development Centre at Fikkal of Illam district in 1975 [6]. Commercial cultivation of large cardamom under agro-forestry system has become boom in the sloppy areas where cereals, vegetables and fruits enterprises becomes unfavourable [7]. This has been practiced commercially in Tehrathum of Nepal since last 25 years. However, Taplejung is the largest cardamom producing district of Nepal followed by Sankhuwasabha, Panchthar and Illam. At present, we can see that production and export of large cardamom is declining in Nepal. New competitors have penetrated the market of large cardamom and their products are by far cheaper than that of Nepal [8]. The price of large cardamom has dropped significantly to almost Rs. 850 per kg in 2018 which was more than 2500 in 2014 [9]. Price fluctuation and several viral diseases have decreased the charm of large cardamom farming among the farmers of Nepal.

Cardamom(Small and large) is highly concentrated to two major cardamom producing countries Guatemala and India, which accounts for about $70 \%$ of the global production of this spice crop. Agricultural Marketing, an integral part of agricultural development requires efficiency to acquire accelerated economy in the agriculture [10].

\section{METHODOLOGY:}

For this review mostly research paper and articles were studied and based on those findings were made. Secondary data were collected from the publication of GoN, MoAD, Agribusiness Promotion and Statistics Division, International Trade Promotion Section. Data were also extracted from publication of GoN, MoAD, Monitoring Evaluation and Statistics Division, Agri Statistics Section. Print media such as national newspaper were also consulted to get acquainted with the recent trend of cardamom production and marketing.

Data processing was carried out by examining, categorizing, editing, tabulating and recombining information. Simple statistical tools were used to estimate frequency, percentage and average values from the collected data. Likewise, Microsoft excel 2007 was used for analysis and findings were made from the obtained results. RESULTS AND FINDINGS

\subsection{NATIONAL PRODUCTION:}

Over $80 \%$ of the total national production of large cardamom is concentrated to four major districts namely Taplejung, Panchthar, Ilam and Sankhuwasabha.

\begin{tabular}{|l|l|l|l|l|}
\hline Districts & Total Area (Hectare) & $\begin{array}{l}\text { Productive } \\
\text { (Hectare) }\end{array}$ & Yreald (kg/ha) & Production (tons) \\
\hline Taplejung & 4500 & 4150 & 2490 & 600 \\
\hline Sankhuwasabha & 2824 & 2200 & 1129 & 513 \\
\hline Panchthar & 1950 & 1737 & 798 & 460 \\
\hline Illam & 1600 & 1200 & 576 & 480 \\
\hline Khotang & 1404 & 961 & 440 & 458 \\
\hline Terhathum & 730 & 637 & 250 & 393 \\
\hline Dhankuta & 299 & 165 & 97 & 59 \\
\hline Bhojpur & 600 & 385 & 193 & \\
\end{tabular}

Table 1 : Major cardamom producer by districts(2016-17) in Nepal

Source : (STATISTIC AGRICULTURE BOOK, 2016)[11] .

From the above table, we can see that Taplejung is the largest large cardamom producing district having cultivated area of 4,500 hectares producing about 2,490 tons worth 6 billion rupees (about US $\$ 570$ million). Highest producer Taplejung is followed by Sankhuwasabha, Panchthar and Illam with production of 1129 tons, 798 tons and 576 tons respectively. 


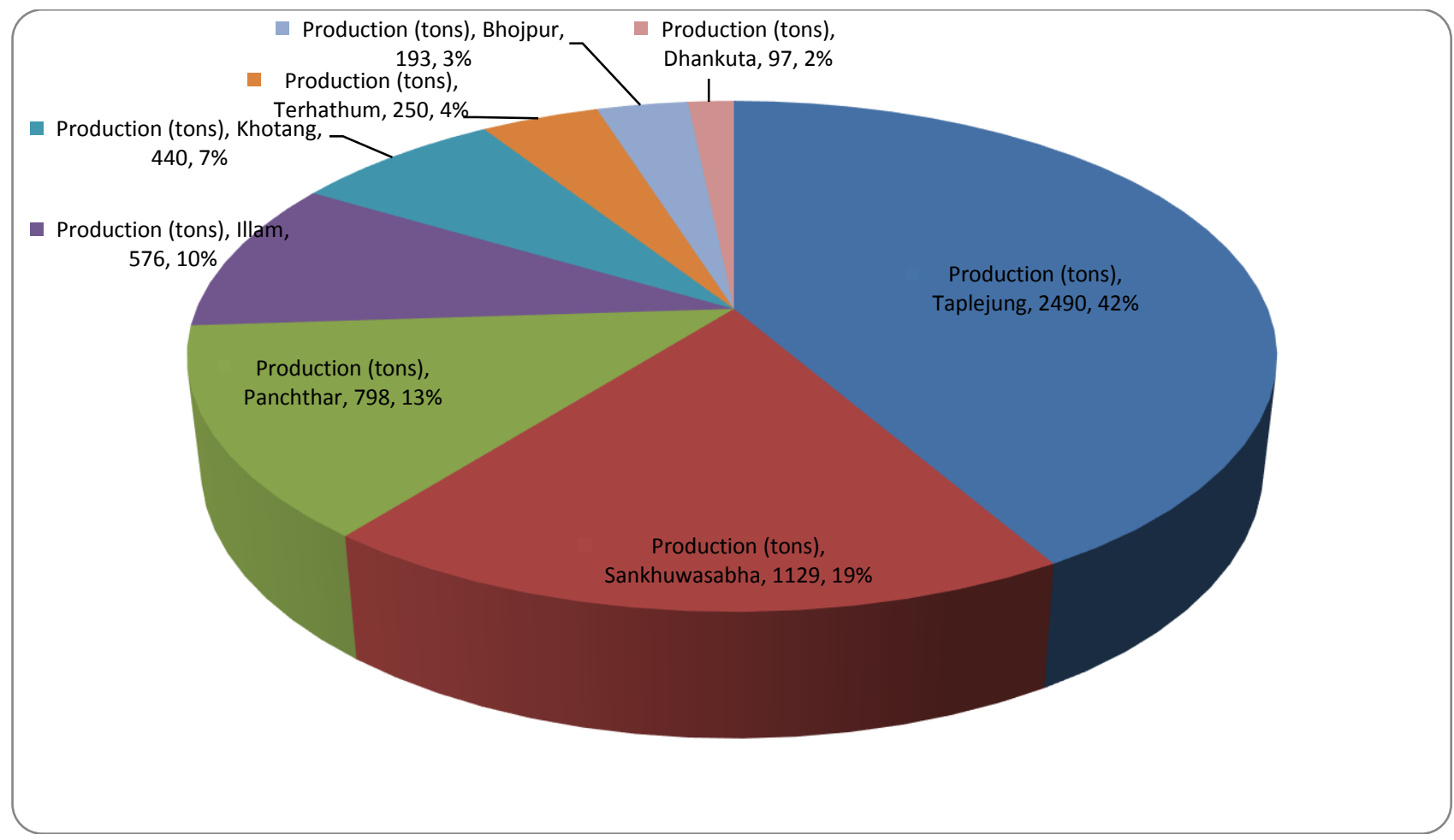

Figure 1: Production of large cardamom in 7 major districts of Nepal Source : (STATISTIC AGRICULTURE BOOK, 2016)[11] .

\section{Area, Production and Yield of Large cardamom}

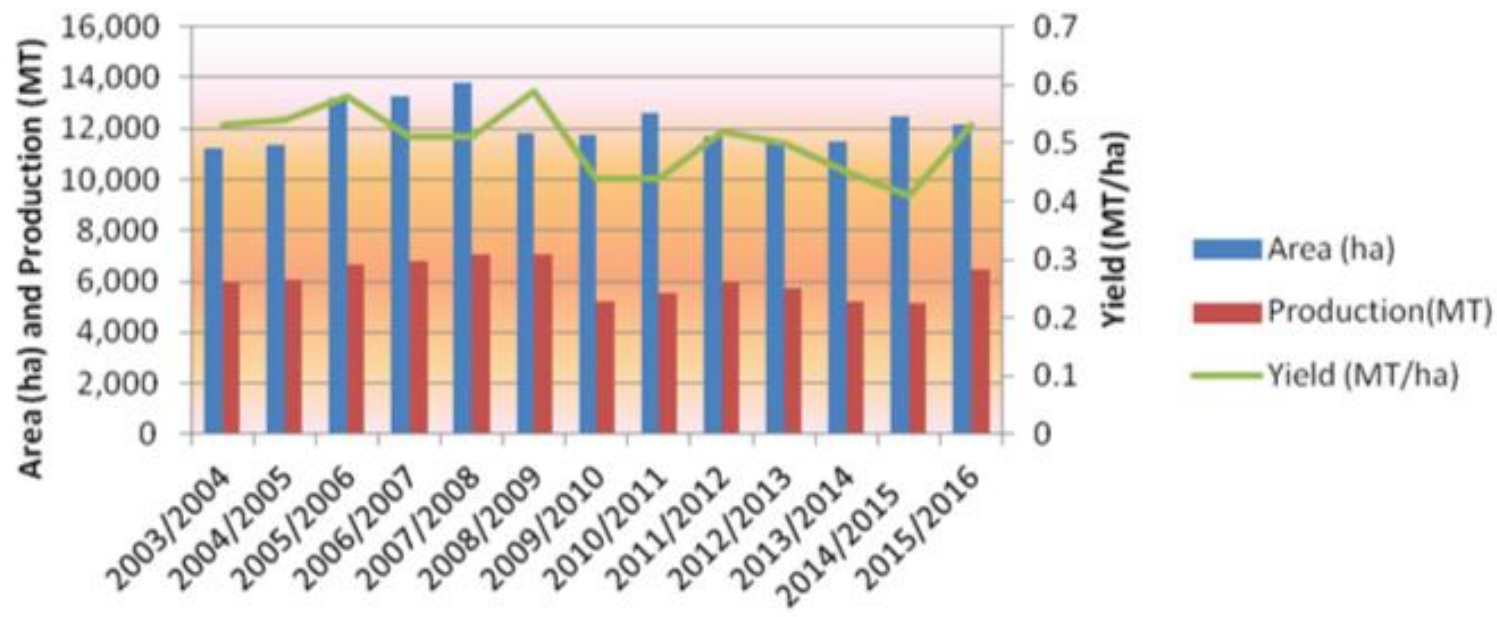

Figure 2: Productivity of Large Cardamom in Nepal, 2003-2016

Source: (MoAD, 2017) [12].

The productivity of large cardamom in Nepal is far below to average yield which is $531 \mathrm{~kg} / \mathrm{ha}$. The productivity of large cardamom grew modestly from $2003 / 2004$ to $2008 / 2009$ and the productivity decreased sharply to the following year. This may be due to incidence of several diseases like chirke, furke, etc and also climate change that caused collapsing of the orchard especially in Illam district. Similarly, the productivity has significantly increased after 2014/2015 to 2015/2016.This increment might be due to awareness among farmers, increasing donor agencies, use of improved technology, high demand of the product, etc.

\subsection{NATIONAL MARKETING:}

For the export of the cardamom from the producing district, cardamom is firstly sent to the local traders. From the local tra ders the product reaches to the district level and regional traders. After that regional traders sell the product to India through border. There are many middlemen involved during the process. They may be organization, wholesellers, local collectors or district collectors. It was found that until now no organization have been involved in the trading of cardamom in Nepal. Wholesellers were also very few in number and they were located only in Jhapa. 


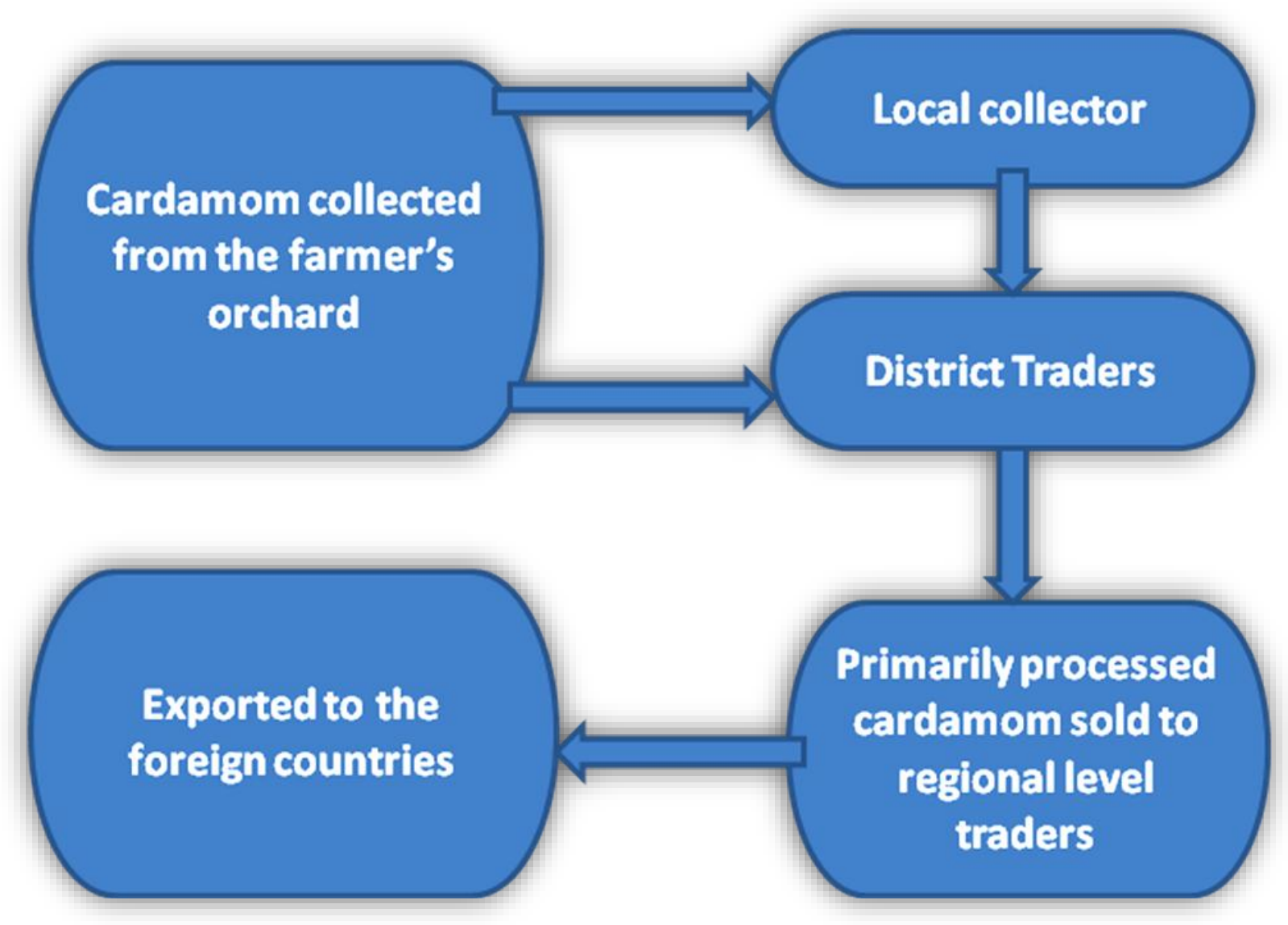

Figure 3: Flow of cardamom from farmers to foreign countries

Source: (Bhandari \& Bhandari, 2018)[7].

Table 2 Actors involved in the export of Cardamom in Nepal

\begin{tabular}{|l|l|l|l|l|l|}
\hline S.N. & Districts & Local collectors & District traders & wholesellers & Organizations \\
\hline 1 & Illam & 112 & 32 & 0 & 0 \\
\hline 2 & Panchthar & 98 & 28 & 0 & 0 \\
\hline 3 & Taplejung & 125 & 25 & 0 & 0 \\
\hline 4 & Jhapa & 0 & 0 & 11 & 0 \\
\hline
\end{tabular}

Source:(MoAD, 2015)[4].

Before exporting the products farmers also do drying, grading and packaging of the product. For drying traditional method as simply drying in sun was mostly adopted. Other semi improved and improved method using sophisticated machines were rarely seen. Grading of the product was done mostly on the basis of tail cutting. However, some farmers also graded large cardamom on the basis of color and their size. To export packaging of the product is must. So packaging was done in jute, plastic or plastic in jute. The most effective and mostly adopted method of packaging was putting plastic inside the jute bag and keeping cardamom in that plastic.

Table 3 Drying, Grading and Packaging of cardamom

\begin{tabular}{|l|l|l|l|l|l|l|l|l|l|}
\hline & \multicolumn{2}{|c|}{ Drying } & \multicolumn{2}{c|}{ Grading } & \multicolumn{3}{c|}{ Packaging } \\
\hline & Traditrict & $\begin{array}{l}\text { Semi } \\
\text { improved }\end{array}$ & Improved & Size & Colour & $\begin{array}{l}\text { Tail } \\
\text { cutting }\end{array}$ & Jute & Plastic & $\begin{array}{l}\text { Jute } \\
\text { with } \\
\text { plastic } \\
\text { inside }\end{array}$ \\
\hline Illam & 94 & 5 & 1 & 8 & 5 & 87 & 65 & 10 & 25 \\
\hline Taplejung & 98 & 2 & 0 & 5 & 2 & 93 & 80 & 5 & 15 \\
\hline Panchthar & 95 & 5 & 0 & 7 & 2 & 91 & 85 & 5 & 10 \\
\hline
\end{tabular}

Source: (MoAD, 2015) [4].

$$
\text { 3.3 GLOBAL PRODUCTION: }
$$

NEPAL:

Nepal is the world's largest producer of Large cardamom in the world, followed by India and Bhutan [13], with annual production exceeding 6000 tons and productive land of 14875 hectares cultivated in 46 districts of the country [9]. According to the report, average annual production of Nepal exceeds 6600 tons, which is about 55 percent of the average annual world production of around 12000 tons.

INDIA:

India is the second largest producer of large cardamom with an annual production of 4850 tons, with productive land of 26387 hectares, and exporting 665 tons worth Rs. 8403.90 lakhs in the year 2015-16 [14]. According to the report, it is mostly grown in Sikkim (4075 tons) and Darjeeling district of West Bengal (775 tons) of India. Pakistan is the major importer of Indian large cardamom.

BHUTAN:

Bhutan has average annual production of 1500 - 2000 tons making it the third largest producer of large cardamom in the world [15]. According to the report, Jigmecholing and Chuzom gewogs are the most popular large cardamom growers in Sarpang district, southern Bhutan.

Guatemala, India, Srilanka, Tanzania, El Salvador, Vietnam, Laos, Cambodia and Papua New Guinea are the major cardamom (Small and Large combined) growing countries. 
Guatemala is the largest producer of cardamom (small and large combined) in the world. The 2016-2017 harvest of cardamom in Guatemala ended on September 30 with 29700 tons sold, produced by 350 thousand families and provided more than $60 \%$ of the volume of cardamom sold in the world, which meant 30\% increase compared to the revenues generated between 2015 and 2016. In 2017, cardamom exports from Guatemala totaled \$367 million, and the $60 \%$ increase compared to the previous year which was mainly due to an increase registered in the price of cardamom on the international market over the past year, as it increased from \$6.42 per kilo in 2016 to \$10.27 per kilo in 2017 [16].

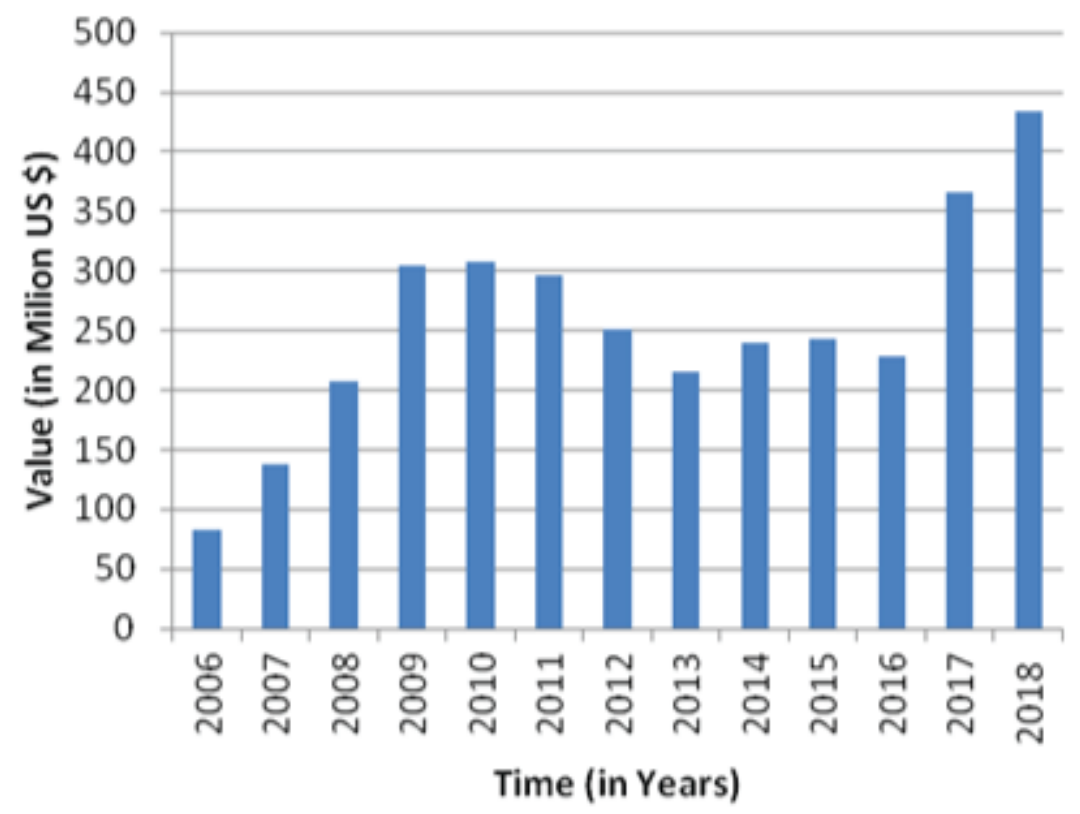

CARDAMOM

Figure 4: Export of cardamom from Guatemala in $2006-2018$

Source: (BancoDeGuatemala, 2019) [16].

Above table shows that the export of cardamom increased substantially from 2006 to 2010 and then it decreased to 2013 . It then increased gradually to 2015, after 2016 to 2018 significant growth in export of cardamom was seen.

3.4 NEPALESE CARDAMOM IN GLOBAL MARKET:

Nepal is one of the major exporters of cardamom in the world. About $90 \%$ of the cardamom produced in Nepal is exported to India through Birtamode in Jhapa [17-18]. Other markets of Nepal are Singapore, Pakistan, Canada and UAE. Nepal earns 20 million dollars annually from cardamom production out of which 12 million comes from the export of the product [19].

Table 4: Amount exported from Nepal to the other country in 2014

\begin{tabular}{|l|l|l|l|}
\hline S.N. & Country & Quantity in kg & Value \\
\hline 1 & India & 5879702 & 3875674562 \\
\hline 2 & UAE & 18000 & 15501059 \\
\hline 3 & Canada & 1000 & 1177650 \\
\hline 4 & China & 3000 & 240000 \\
\hline 5 & Nicaragua & 50 & 58000 \\
\hline
\end{tabular}

Source: (SNV Agriculture Report, 2014) [20].

Above table shows that India is the major importer of large cardamom from Nepal with import value 300 million. UAE, Canada, China and Nicaragua follow India in the list. We can see that countries like Singapore and India fall under both major exporter and importer. Many researchers have shown that though both countries produce large amount of cardamom themselves a large share of their export is imported from Nepal.

Table 5: Major exporter of cardamom (Small and large cardamom combined), HS 090831

\begin{tabular}{|l|l|l|l|}
\hline Exporters & $\begin{array}{l}\text { Exported quantity } \\
\text { In 2015 (\%) }\end{array}$ & $\begin{array}{l}\text { Annual growth rate in vaue, } \\
2014-2015(\%)\end{array}$ \\
\hline Guatemala & 61.6 & -1 & 1 \\
\hline India & 17.9 & 13 & 21 \\
\hline Nepal & 10.9 & 3 & 31 \\
\hline Singapore & 3 & -4 & 19 \\
\hline Indonesia & 2 & -18 & -23 \\
\hline
\end{tabular}

Source : (International Trade Centre, 2016) [18].

Above table shows that, Guatemala is the largest exporter of cardamom (small and large combined) in the world followed by India, Nepal, Singapore and Indonesia exporting $61.6 \%, 17.9 \%, 10.9 \%, 3 \%$ and $2 \%$ respectively of the global cardamom trade. According to ITC in 2015, Guatemala alone exported 33,400 tons of Cardamom to the international market which was $61.6 \%$ of the word export. Similarly, India and Nepal exported 6,200 and 5,300 tons of cardamom respectively to the world market contributing $17.9 \%$ and $10.9 \%$ respectively of the world export.

Table 6: Major importers of cardamom in global market

\begin{tabular}{|l|l|l|l|}
\hline Importers & Imported quantity in 2015 (\%) & 5 -year CAGR (\%) & $\begin{array}{l}\text { Annual growth rate in value, 2014- } \\
2015(\%)\end{array}$ \\
\hline Saudi Arabia & 29.8 & -7 & 7 \\
\hline United Arab Emirates & 21.8 & 25 & 13 \\
\hline India & 13.1 & 43 & 58 \\
\hline Bangladesh & 4 & 5 & 3 \\
\hline Singapore & 2.8 & 6 & 16 \\
\hline
\end{tabular}

Source : (International Trade Centre, 2016) [21].

Above table shows that, Saudi Arabia is the largest consumer of cardamom (small and large combined) in the world followed by United Arab Emirates, India, Bangladesh and Singapore respectively. According to ITC in 2015, Saudi Arabia alone imported 11,200 tons of Cardamom from the world market which was $29.8 \%$ of the world import. Similarly, United Arab Emirates imported 11,000 tons from the world market which was $21.8 \%$ of the world import. 
These top two importers contribute to $51.6 \%$ of cardamom from the global market.

\section{DISCUSSION}

Only few districts of the country are actively involved for the production of large cardamom. The average productivity of large cardamom in Nepal is only $531 \mathrm{~kg} / \mathrm{ha}$, while, Morang and several districts of eastern terai have higher productivity of large cardamom i.e.948 kg/ha [10]. This means that the average productivity is far less than the normal. This might be due to the fact that in recent years Nepalese farmers have started facing several problems in cardamom production such as spread of viral diseases, poor soil conditions, price fluctuation, etc. Viral diseases like Chirke and Furkey has massively reduced yield in Taplejung district. Price fluctuation has become the major problem because Price fixing of Nepalese cardamom is governed widely by the Indian markets [22].

The price of large cardamom was 2,700 in the year 2014 but it has dropped to Rs.850 in 2018, a drop of about 68\% [23]. The price of large cardamom reached as high as Rs.3000 in 2016 but the price could not make its pace. The demand for Nepalese cardamom in the global market is decreasing. This is due to the fact that when Nepal exports large cardamom to the world market, 'Duplicate Large Cardamom' is the major problem. In recent years, encouraged by the high economic return from large cardamom, major green cardamom producing countries namely Guatemala, China and Vietnam began to export 'duplicate' large cardamom to Pakistan. This duplicate large cardamom are different in shape and smell but they are mixed with the original Nepali large cardamom to gain higher profit. This trend among traders in Pakistan has decreased the large cardamom export from India to Pakistan. Since, $99 \%$ of the total cardamom production is exported to India alone, it has indirectly but negatively impacted on large cardamom sector in Nepal.

Another problem of large cardamom export is absence of unique HS code at six-digit level [8]. HS code used for Large cardamom export is 09083110 [24]. Large cardamom (Black cardamom) shares the same HS code to the green cardamom, which has similar appearance and is more widely produced globally. Therefore, by using the HS code 090831 which is common for both black and green cardamom, it is not possible to precisely record the trade flow of large cardamom globally.

\section{CONCLUSIONS:}

Though Nepal is the largest producer of large cardamom in the world its productivity is still not satisfactory. Several factors such as traditional method of farming, lack of access to modern technology, incidence of disease and fragmented landholding have come into play. Furthermore, dwindling quality of cardamom produced in Nepal and production of duplicate cardamom by competing market have resulted in decrement of both demand and price of it in international market. Therefore, to increase the production and enhance the marketing of this high value spice the government and related authority should make necessary intervention and address this issue. By collaborating with national and international organizations government should help farmers gain access to technologies that can aid in boosting its productivity. In addition, in farm and off farm researches about proper cultivation and processing of cardamom and subsequent dissemination of knowledge to commercial farmers are mandatory to boost productivity of the spice crop. This can help Nepal gain advantage in international market at times when the experts and analyst are predicting the compound annual growth market would rise up by 2.35 in next three years.

This review mainly highlights status of production and marketing of cardamom in Nepal and also provides comparative data of these dimensions of different countries. It points out problems in the production and marketing of cardamom in Nepal which can aid in formulating policies that can ameliorate the problems seen in the process of cardamom farming, processing and marketing and also locate potential markets of this spice crops in the world. The review has opened prospects for the detailed study on different factors that has hindered rise in productivity and market effectiveness of this commodity in Nepal and about different solutions to these problems in the future.

\section{BIBLIOGRAPHY:}

[1] Singh, K. A., Rai, R. N., Patiram, Bhutia, D. T. 1989. Large cardamom (Amomum subulatum Roxb.) plantation - An age old agroforestry system in Eastern Himalayas. Agroforestry Systems, 9(3), 241-257. https://doi.org/10.1007/BF00141087

[2] Sharma, E. K., Singh, K., Sharma, R., Sharma, G. 2000. A Boon for Mountain Populations: Large Cardamom Farming in the Sikkim Himalaya. Retrieved November $\quad 9, \quad$ 2018, from https://www.researchgate.net/publication/250069601_A_Boon_for_Mountain_Populations_Large_Cardamom_Farming_in_the_Sikkim_Himalaya

[3] Singh, A. I., Pothula, A. K. 2013. Postharvest Processing of Large Cardamom in the Eastern Himalaya. Mountain Research and Development, 33(4), 453-462. https://doi.org/10.1659/MRD-JOURNAL-D-12-00069.1

[4] MoAD. 2015. Trade Flow Analysis of Large Cardamom in Eastern Region. Retrieved from http://www.moadwto.gov.np/noticefile/Trade Flow Analysis of Large Cardamom_1449033478.pdf

[5] Thakur, K. 2010. Knowledge Innovation Repository of Agriculture in North East. ICAR.

[6] Go International Project. 2013. An export promotion initiative from Confederation of Nepalese Industries (CNI). Retrieved November 9, 2018, from http://www.gointernational.org.np/portal/index.php?p1=catalogue\&p2=3

[7] Bhandari, N., Bhandari, T. (018. Marketing and Socioeconomics Aspects of Large Cardamom Production in Tehrathum, Nepal. Journal of Nepal Agricultural Research Council, 4(1), 79. https://doi.org/10.3126/inarc.v4i1.1969

[8] National Sector Export Strategy. 2017. Nepal National Sector Export Strategy Large Cardamom 2017-2021. Government Of Nepal. International Trade Centre, 116. Retrieved From Http://Www.Intracen.Org/

[9] The Kathmandu Post. 2018. Nepali large cardamom being pushed out of world markets. Retrieved November 10, 2018, from http://kathmandupost.ekantipur.com/news/2018-03-02/nepali-large-cardamom-being-pushed-out-of-world-markets.html

[10] GoN. 2015. Nepal - Market Price Ratio of Agriculture Commodities 2060-2071, Annual price ratio. Retrieved October 21, 2018, from http://cbs.gov.np/nada/index.php/catalog/47/study-description

[11] Statistic Agriculture Book. 2016. Statistical Information On Nepalese Agriculture Government Of Nepal Ministry Of Agricultural Development Monitoring, Evaluation And Statistics Division Agri Statistics Section. Singha Durbar, Kathmandu, Nepal. Retrieved From Http://Moad.Gov.Np/Public/Uploads/1142453195-Statistic Agriculture Book 2016.Pdf

[12] Moad. (2017). Statistical Information On Nepalese Agriculture Government Of Nepal Ministry Of Agricultural Development Monitoring, Evaluation And Statistics Division Agri Statistics Section. Singha Durbar, Kathmandu, Nepal: Statistic Agriculture Book. 
[13] Gautam, A. 2017. Large cardamom price plunges three-fold. Retrieved October 19, 2018, from http://kathmandupost.ekantipur.com/news/2017-0415/large-cardamom-price-plunges-three-fold.html

[14] Bhutia, K. C., Bhutia, S. O., Chatterjee, R., Pariari, A. 2017. Post harvest processing and marketing of large cardamom in India. Journal of Crop and Weed, 13. West Bengal. Retrieved from http://www.cropandweed.com/archives/2017/vol13issue3/13-3-44.pdf

[15] RoyalSpices. 2017. Bhutan Big Cardamom. Sugandha Bhawan, Cochin. Retrieved from http://www.royalspices.com/products/big-cardamom/bigcardamom-from-bhutan/

[16] BancoDeGuatemala. 2019. CentralAmericaData:: The Regional Business Portal, Bank of guatemala. Retrieved November 9, 2018, from https://en.centralamericadata.com/en/article/home/Good Figures for Cardamom

[17] Ghimire, R. 2014. Federation of Large Cardamom Entrepreneurs of Nepal (FLCEN), 35-39.

[18] Maharjan, P. 2014. Large cardamom (Elaichi) and its trade in Nepal.

[19] Munankarmi, N., Shrestha, R., Rana, N., Shrestha, J., Shrestha, S., Koirala, R., Shrestha, S. 2014. Genetic Diversity Assessment of Acid Lime (Citrus Aurantifolia Swingle) Landraces of Eastern Nepal Using RAPD Markers. International Journal of Applied Sciences and Biotechnology, 2(3), 9.

[20] SNV Agriculture Report. 2014. Alleviating poverty through cardamom farming—An experience of SNV. Retrieved from http://www.snv.org/

[21] International Trade Centre. 2016. Trade Map - Trade statistics for international business development. Retrieved October 19, 2018, from https://www.trademap.org/Index.aspx

[22] Poudel, M. P., Chen, S. 2012. Effect of Production on Large Cardamom Price Variability in Nepal | Request PDF. Journal of International Agricultural Trade and Development, 8(1), 99-108.

[23] Portel, P. 2018. Large cardamom price in freefall, down 68pc. Retrieved October 19, 2018, from http://kathmandupost.ekantipur.com/printedition/news/2018-03-01/large-cardamom-price-in-freefall-down-68pc.html

[24] HS Code of Black cardamom Import Export Classification. 2016. Retrieved October 18, 2018, from https://www.seair.co.in/black-cardamom-hscode.aspx 